\title{
Comparative Study of Students' Learning Loss during Covid-19 Pandemic and What It Means for Students in Manggarai
}

\author{
Angela Merici G Adem ${ }^{1}$, Maria Evarista O Barut ${ }^{2}$ \\ Teachers College Columbia University ${ }^{1}$ \\ State University of Yogyakarta, Indonesia ${ }^{2}$ \\ \{aga2146@tc.columbia.edu ${ }^{1}$, mariaevarista.2018@student.uny.ac.id ${ }^{2}$ \}
}

\begin{abstract}
The school closure for over a year due to covid pandemic strikes has forced more than 1.6 billion students worldwide to switch their learning process into distance learning. This unprecedented event results in some setbacks in the learning process, and among the detrimental effects is learning loss. This bibliographic review aimed to compare the degree of learning loss due to the covid pandemic in several places worldwide and evaluate what it means for the learning situation and progress in Manggarai Regency, East Nusa Tenggara (ENT). From this study, we found a massive learning loss during the learning-from-home setting for students in many places around the world, including Indonesia. The degree could be varied depending on the way the learning process is conducted. By reflecting on the learning loss-related research from places worldwide, learning loss has the potential to be more detrimental for students in Manggarai since the infrastructure to support remote learning is not adequate enough and not equally distributed. This situation leads to only a limited number of learning instructions that can be applied to support the instruction. Therefore, this paper recommended a more empirical research to measure the magnitude of learning loss in Manggarai while also taking some mitigation strategies to deal with the possible loss.
\end{abstract}

Keywords: Learning loss; COVID-19; Comparative; Manggarai

\section{Introduction}

When covid-19 became a global pandemic in March 2020, most schools worldwide prompted an unprecedented shutdown and switched the learning process into distance learning. The action was taken to minimize the transmission of the virus at the schools and students-tofamily transmission. This closure happened in almost 180 countries worldwide, resulting in around 1.6 billion students unable to continue their face-to-face learning process at school (Azevedo, J.P., et.al. 2020). Meanwhile, for Indonesia, almost 69 million students face a significant risk of distance learning during government-mandated school closures to prevent Covid-19 transmission (Arsendy, S., et al. 2020).

During the school closure, some strategies are taken by school administrators and teachers to continue the learning process, including using online learning platforms (Zoom, google meet or google classroom), television and radio, paper packets, online messaging platforms. However, other students have their learning process stopped altogether (Bazaldua, D.L., et al. 2020). Teachers, parents, and educators realize the potential cost of this remote learning since 
the school systems were overwhelmed and unequipped to deal with the sudden learning switches. However, based on a study in the United States, the effectiveness of remote learning remains unclear since most students and teachers had minor experiences with online instruction and the case of the digital divide that happens in many places (Kuhfeld, M., et al. 2020). Moreover, Asian Development Bank (ADB) mentioned several reasons that make remote learning less effective, such as the unplanned nature, the involvement of younger-age children, and distractions at home that keep students focused away from studying (ADB, 2020).

The less effective distance learning could lead students to have different levels of knowledge and skills, with disadvantaged students suffering the most loss. This condition is called learning loss, which is defined as "the stagnation or decrease in student achievement relative to expected performance attributed to the disruption of in-person schooling either due to seasonal factors (e.g., summer breaks) or emergencies (e.g., Covid-19 Pandemic or natural disaster)" (Bazaldua, D.L. et al. 2020). While learning loss is quite common for countries with longer seasonal breaks, like the United States, Canada, or some European countries - which could lead to almost a month of loss -, the effects of more than a year of school closure could be more worrisome. However, according to the World Bank, learning loss could vary based on the extent of learning while schools were closed.

This bibliographic review is aimed to compare the degree of predicted learning loss in several countries around the world, including Indonesia. The result also will be used to reflect the potential implication of distance learning to the learning loss in the Manggarai Regency, with a hypothesis that the learning loss in Manggarai will be significant. Further recommendations also will be explicitly proposed on the policy to remedy the learning loss.

\section{Research Methods}

This study is a literature review which aims to describe learning losses that occur around the world and what it means for students in Manggarai by synthesizing the findings from various scientific literature and related sources. The literatures were obtained by searching on Google Scholar, which is an electronic database for journals, books, documents, etc. The authors use keywords such as Learning Loss and COVID-19 (all written in quotation marks). For those keywords, there are 1892 results obtained.

The results are then carefully selected by excluding some articles that just slightly mention the "learning loss" term without doing the comprehensive discussion about the topic. We also excluded some results from website or blog articles that were written not based on scientific research process. The study also only focuses on the learning loss of students in primary and secondary school, so the findings related to college or university students will be excluded. In addition, we also added some government documents that contain the data of socio-economic status of the population in Manggarai as well as some educational reports of students in Manggarai. Based on the process, there are a total of 28 articles that will be reviewed. 


\section{Conceptual Review}

\subsection{Learning loss}

Learning loss is more common in countries with longer seasonal breaks, e.g. summer or endof-year academic breaks. This condition is when students come back to school after around 4 6 weeks breaks with their achievement lower than where they were at the beginning of the break. The World Bank formally define the condition as "the stagnation or decrease in student achievement relative to expected performance attributed to the disruption of in-person schooling either due to seasonal factors (e.g summer breaks) or emergencies (e.g Covid-19 Pandemic or natural disaster)" (Bazaldua, D.L., et al. 2020). Pier et al (2021) also use learning loss to describe a decline in students' knowledge and skills when educational progress does not occur at the same rate as in previous years.

Research by Cooper et al. in 1996 showed that the average student score in the fall is about 0.1 standard deviation below their spring average, which indicates the approximate loss is one month of instruction (McCombs, J., et al. 2011). The degree of loss could be varied, with students from more disadvantaged households are more likely to experience the learning loss than their more affluent peers. These less fortunate students had fewer opportunities to engage in remote learning settings due to the impact of the digital divide, lack of learning infrastructure at home, or lack of parental involvement and support (Bazaldua, D.L, et al, 2020). UNICEF specifically reports that children from disadvantaged households usually experience missing learning opportunities because they lack access to remotely delivered instructional content. Children in poorer families are less likely to have computers, internet, TV, radio, or smartphones (Jenkins \& Benerji, 2020).

The World Bank (2020) describes three possible scenarios for learning loss, (1) a decrease in all students' average level of learning, (2) an enlarging distribution of learning performance due to profoundly unequal effects of the pandemic on different communities, or (3) a significant rise of students with meagre achievement, partially attributed to massive dropouts. Brown et al. (2020) also identified the characteristics of students with a high risk of learning loss, including (1) students who are partially or fully disengaged from school education; (2) students in need of one-on-one support; (3) students who struggle with literacy and numeracy. Similarly, McKinsey (2020) differentiates learning loss relative to access to remote learning (Dorn, E., et al, 2020). Students who experienced average-quality remote learning continue to progress but slower than if they remained in school. Students getting lower-quality remote learning are generally stagnating at their current grade levels. Lastly, students who are not getting instruction are all possibly losing significant ground. All these conditions contribute to the different magnitude of learning loss experienced by students around the world.

\subsection{Short-and Long-Term Impacts of Learning Loss}

Before the pandemic, education systems worldwide have faced a challenge on learning poverty and educational inequality. School closure due to Covid will only exacerbate the current situation. 
In the short term, Covid-19 learning loss will widen the achievement gap. Students from more affluent backgrounds could afford high-quality homeschooling, more advanced learning resources, have access to distance learning infrastructure, and have adequate parental support (Jenkins \& Benerji, 2021; Rothstein, R. 2020). Meanwhile, disadvantaged students have far less access to these resources and experienced low quality of remote learning, making learning loss and lower academic performances more possible and more significant. Aside from broadening the achievement gap, there is a potential increase in high school dropout rates. McKinsey's research in the US showed the estimation that two to nine percent of high school students could drop out of school during the covid-19 pandemic and school closures (Dorn, E., et al, 2020). Meanwhile, last year, the World Bank prediction showed that 7 million students are dropping out, and the numbers could go upward as the economic recession plays an important role (Azevedo, et al, 2020).

The current learning loss is projected to cause earning loss and negatively impact the economy in the long run. The World Bank predicts that on a global level, school closure for even five months could result in learning loss that has a present value of $\$ 10$ trillion, equal to $16 \%$ of government investment in education (Azevedo, et al. 2020). Montenegro and Patrinos (2014) mentioned that every additional year of schooling increases the annual earnings by $9.7 \%$, and every year of schooling lost is equivalent to $9.7 \%$ less in potential earnings. In addition, ADB (2020) predicts that every student affected by covid-19 school closures in developing Asia could lose an estimated $\$ 180$ every year, equivalent to a $2.4 \%$ decrease in average annual earnings.

The percentage of decline is highest in East Asia (4.0\%), and South Asia (4.0\%), where school closures are longer. McKinsey's (2020) studies in the United States found that the students with learning loss will probably be less skilled and thus less productive, and by 2040 this could be translated into the country's GDP loss of $\$ 173$ billion to $\$ 271$ billion a year (Dorn, E. et al. 2020). Many countries will possibly suffer the equivalent of a more significant loss in their economy if today's learning loss is not well-handled.

\section{Discussion}

\subsection{Covid-19 Learning Loss: A Comparative Study from Several Countries}

The school closure due to Covid-19 in most of the countries worldwide makes the learning loss unavoidable for the majority of the students. Evidence showed that quarantined students tend to have short learning hours compared to when they have face-to-face instruction. In addition, many students spending most of their time at home may feel emotionally exhausted, stressed, or anxious, which could negatively impact their concentration to learn. Lack of interaction with peers or teachers also leads students to feel unmotivated to engage in learning activities (Di Pietro et al. 2020).

All these conditions contribute to students' learning loss despite the countries they are coming from. At the global level, Azevedo et al. (2020) estimate that the school closure amid COVID-19 could result in a loss of 0.3 to 0.9 years of Learning Adjusted Years of Schooling (LAYS). This will bring down the effective years of schooling that students achieve during their lifetime from 7.9 years to between 7.0 and 7.6 years.

The Netherlands, which undergoes only a relatively short lockdown ( 8 weeks), estimates about three percentile points or 0.08 standard deviations of learning loss. The effect is equivalent 
to one-fifth of a school year, the same period that schools remained closed (Engzell, P. et al. 2021). Research in Belgium also showed that lockdown and school closure during the covid-19 pandemic resulted in a learning loss of 0.19 standard deviation in mathematics and 0.29 standard deviation in the Dutch Language (Maldonado \& De Witte, 2020).

In the United States, the learning loss will impact black and minority disadvantaged students more than their affluent white counterparts. Studies by McKinsey showed that, on average, students in the US could lose 5 to 9 months of learning by the end of June 2021 . Students of colour could be 6 - 12 months behind, while their white peers could lose eight months (Dorn, E., et al, 2020). Another in-depth study in the US that explicitly identifies the learning loss of grade 3 to 8 students estimates that if students could attend school in fall 2020 , they will have 32-37 per cent less progress in reading than they would have in a typical school year. The projection is higher for mathematics, with 50-63 percent of estimated loss (Kuhfeld, et al, 2020).

\subsection{Learning Loss in Indonesia}

\subsubsection{Description of Distance Teaching and Learning}

The Ministry of Education and Culture (MoEC) estimates 97,6\% of schools in Indonesia have employed distance learning since March 2020. However, the following study by the MoEC and Ministry of Religious Affairs (MoRA) found that a mere 2.4 percent of teachers and principals did not implement distance learning. To support the implementation of distance learning, two kinds of learning approaches could be used namely online learning and offline learning.

Online learning commonly utilizes computer technology and internet support in its process. It could take the form of synchronous learning, which uses computer and online services such as video calls, video conferences, etc., while asynchronous learning is the learning with indirect online communication through media such as e-mail, forums, reading, and writing online documents through the world wide web, and Learning Management System (LMS). Meanwhile, offline learning is the learning process interaction without utilizing computer technology and the internet. Instead, it employed electronic devices such as television and radio broadcast or non-electronic devices by sending take-home packages to students, referencing textbooks for lessons.

The study of Indrawati et al. (2020) found that a total of 23,0\% of students experienced offline learning using electronic devices or multimedia (e.g: television, radio, or SMS and phone call), $20 \%$ of students engaged in asynchronous online learning through WhatsApp, and only about $10,1 \%$ students learned synchronously by using Zoom, Skype, or Google Meet. A similar result was found on the MoEC primary school survey of 14,668 respondents in April 2020. A total of $70 \%$ of students reported learning through WhatsApp groups, and less than $0.1 \%$ reported learning through websites or school platforms.

\subsubsection{Potential Learning loss in Indonesia}

School closure affects around 69 million students in Indonesia. It means that those students are at risk of experiencing a certain degree of learning loss. The World Bank (2020) uses different scenarios to predict how remote instruction will impact overall students' outcomes and performance in Indonesia, including the country's PISA score (Yarrow, N. et al. 2020). Three scenarios were based on the duration of school closure, current (4-month closure), optimistic (6-month closure), and pessimistic (8-month closure). Using PISA 2018 data, the predicted reading score under the current scenario will decrease by 11 points and lower for the other two scenarios. 


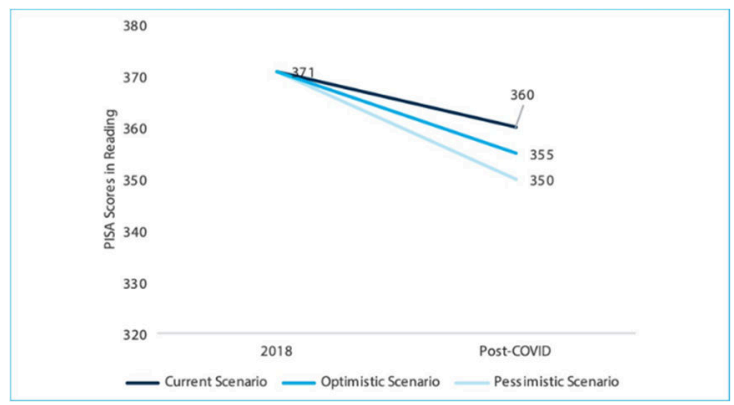

Fig1. Indonesia's predicted post-covid PISA score Source: World Bank Group, 2020

Going further, the Learning Adjusted Years of Schooling (LAYS) score -the difference between years of schooling and the actual years of learning - was used to quantify learning loss, and it was predicted that Indonesia's LAYS score will decrease by around 0.4 to 0.7 points. Therefore, under the current scenario, it is estimated that the LAYS will reduce from 7.9 years to 7.5 years; under the optimistic scenario, it will reduce to 7.4 years; and in the pessimistic scenario, it will decrease to 7.2 years (Yarrow, N. et al. 2020).

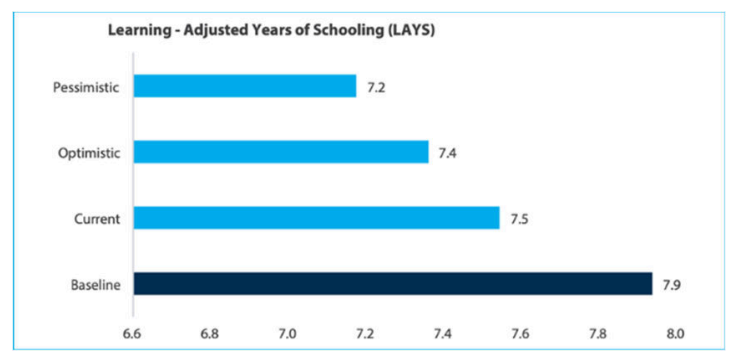

Fig 2. Predicted Post-Covid LAYS Score Source: World Bank 2020

More estimates by the World Bank also showed that if the school closure ended in July 2020, the students could lose four months of learning (Gupta \& Khairina, 2020). The other implication of this prediction is that since the school closure will continue until July 2021 (and could be longer), the loss of learning could be a year or more. One interesting fact that the World Bank highlighted was that the effects could worsen for low-performing students from a more disadvantaged background. These students have limited access to online learning devices or other infrastructure to support remote learning. A similar situation also resonates with students with disabilities who have less access to special services (Yarrow, N. et al. 2020; Gupta \& Khairina. 2020).

As a result, their learning outcome/performance could fall behind their more affluent and/or high-performed counterparts. Thus, while the reality of school closure in Indonesia has been longer than the World Bank prediction, even surpasses the pessimistic scenario, we could assume that the quantity of loss could be more significant. Research by Arsendy, et al, (2020), who specifically examines teaching and learning in Indonesia during school closure, also emphasizes the different degrees of learning loss experienced by certain groups of Indonesian students, which depend on teaching method and teacher-student interaction. They found that 
students being taught in distance learning without target or structure in teaching and their teachers only giving a very minimum to no stimulus were having a higher risk of learning loss. The same condition also applies to students who are in a curriculum-oriented learning environment.

Based on World Bank estimation and the facts on how teaching and learning are delivered, learning loss in Indonesia will be significant and alarming. While the loss could vary based on regions and teaching or learning method applied, the further effects on educational achievement, country's educational reputation on PISA, and even the future economic impact will be lasting.

\subsubsection{The Potency of Learning Loss in Manggarai Regency}

Manggarai Regency is one of the developing areas in Indonesia until 2019; it has been excluded from the developing region list since 2020), with many of the settlers living under the poverty line or lower socio-economic status (SES). Badan Pusat Statistik (Statistic Indonesia) (BPS Manggarai, 2021) elaborates that the percentage of the poor population is $20.34 \%$ which is relatively higher than the percentages of the poor population nationally $(9.74 \%)$. In 2020 , half of the population (aged 15 years old and over) was elementary school graduates $(34.47 \%)$ and elementary school dropouts $(18.06 \%)$. The net participation rate at the university level is only $16.65 \%$. The typical occupation was mostly farmers and animal husbandry workers, accounting for 93.470 people $(54.9 \%)$.

The quality of the education system in Manggarai Regency could be categorized as low. It could be seen from the student's achievement score for the national exam, which is still under qualified in the past few years. In the recent national exam in 2019, a total of $60.89 \%$ of students scored less than equal to 55 (Pusat Penelitian Pendidikan, 2019). Meanwhile, for the teachers, most of them have not been certified yet. The results of the teacher competency assessment show that the average teacher achievement score is 54.23 , which is slightly less than the minimum standard set (Kementerian Pendidikan dan Kebudayaan, 2015). Regarding the school quality, Kementerian Pendidikan Kebudayaan (2019) found that only a small number of secondary schools have been accredited on A-level while most of them have acquired B-level. In fact, for elementary school, $43.4 \%$ of schools have not been accredited yet.

The Central Bureau of Statistics (BPS Manggarai, 2021) reported that only $29.30 \%$ of the population of the Manggarai Regency (aged over five years old) have access to the internet. This percentage is lower than the average percentage in NTT Province, which is $32.4 \%$. The mobile phone ownership in Manggarai (people over the age of five years old) is $40.22 \%$, compared to $96.95 \%$ nationally. The percentage of the population (5 years and over) who use computers is $13.13 \%$. Meanwhile, statistical reports for the proportion of the population (5 years and over) who watch television or listen to the radio broadcast in Manggarai Regency are not yet available.

However, in 2019, the percentages at the province level were $58.90 \%$ and $8.58 \%$, respectively. This percentage is relatively lower than the achievements of most other provinces in Indonesia. Based on the explained condition above, it can be concluded that the population in the Manggarai area still has limited access to technology, information, and communication. Considering SES, academic achievement, and accessibility to digital technology, the student from Manggarai Regency could be categorized as a highly vulnerable student (underprivileged student). Further, these challenging situations also impact the type of learning-from-home approach most likely relevant to implement. As the students potentially have limited support and access to digital facilities and internet connectivity, distance learning with offline approaches would be the best choice. 
By considering all the aforementioned disadvantages- learning, social, economic circumstances, and the digital gap-, and reflecting on several countries' predicted learning loss under similar or different circumstances, the learning loss in Manggarai regency could be significant. The absence of adequate remote learning support forces students to acquire knowledge far from what they need, not to mention the loss of learning motivation due to the less interactive and monotone learning process.

In addition, the students coming from blue-collar families could get a tremendous amount of learning loss since they chose to help their parents to work rather than learning from home. Further, this condition could translate to a wider achievement gap, with students in Manggarai being far left behind.

\section{Recommendations}

The unavoidable cost of school closure during the covid-19 pandemic forces educators, policymakers, teachers, and all related parties to find better and possible ways to recover especially from the potential learning loss. Therefore, this paper will recommend short-term and long-term approachable actions that can be taken.

\subsection{Short Term Approach}

1. Designing High-Quality Distance Learning

One of the essential ways to prevent learning loss is by providing high-quality learning instruction. During these challenging circumstances, teachers must be fully aware of the student's characteristics, assess their learning needs, then adjust the instruction design to ensure students master the maximum amount of learning material. In other words, the learning design must follow the evidence-based strategies with a framework that identifies basic needs and material resources that are essential to support children's wellbeing (Brown et al. 2020).

Meanwhile, planning and implementing instruction is not an easy thing to do. Therefore, teachers must equip themselves with the latest knowledge and skill to adapt well to this situation. The teacher could participate in a relevant professional development program that focuses on promoting the acquisition of different innovative learning methods suitable for distance learning for those who suffer from learning loss.

2. Widen the accessibility of Information and Communication Technology (ICT)

Both online and offline learning has their limitations and challenges in its implementation. However, many studies have proven that online learning is more preferable compared to offline learning. For example, research from Patarapichayatham et al. (2021) showed that students who engaged in online learning using an e-learning program had less learning loss than students who did not engage in online learning. Furthermore, even students in lower SES schools engaged in online learning helped narrow the achievement gap with students in higher SES schools.

In another study from Bielinski, J. et al (2020), students who participated in frequent virtual interactions with teachers, especially one-on-one with video conferencing, and completed homework assignments will likely have smaller losses than students who did not. Online platforms allow flexibility in the way students use them; it can be more personal, at their own pace. This adaptability allows students to explore more of the lessons or materials, including additional support or remediation, and improve their creativity in the learning process.

From those studies, online learning is likely more beneficial to accommodate student's learning needs. So, the availability of digital tools and the equitable distribution of the resources 
is mandatory, especially in remote and rural areas. The exemplary policy already implemented in Indonesia is the subsidiary internet packages for students to support students' online learning. It should also be followed by acquiring the related skill to operate the related supporting device effectively.

3. Strengthen collaboration and communication among parent and school

Parents/caregivers and schools go hand in hand to prevent students from experiencing learning loss by ensuring students are completely engaged in learning. If the student is already experiencing the learning loss, they can collaborate and communicate to provide suitable support so that students are mentally and emotionally ready to resume learning.

\subsection{Long Term Approach}

Long-term approaches can be taken when the schools are ready to reopen.

1. Wide Range of Learning Assessment

Teachers, schools, and school systems will face unprecedented challenges once the school gets clearance to reopen, including the different magnitude of learning loss. Therefore, a comprehensive approach will be required to ensure the possible drawbacks of school closing could be alleviated. One of the essential preparations is to assess student's learning progress during the online learning and after the in-person instruction starts.

As the World Bank advocates, it is essential for key stakeholders in education "to determine where students are in their learning trajectories relative to what had been expected prior to the pandemic" (Bazaldua, et.al. 2020). Assessing students' learning progress includes gathering and evaluating what students know, understand, and can/cannot do so that informed decisions about the next steps in the educational process can be taken (Clarke, 2012). Learning loss during covid-19 school closure results in teachers facing students at different starting points when schools reopen. Therefore, the form of assessments is highly required for teachers, school administrators, and education policymakers since it helps these key stakeholders understand students' performance level once they return, and proper and suitable lesson plans and educational programs can be employed to fulfill students' needs.

The World Bank introduces two forms of assessments, Classroom assessment and LargeScale Assessment, that can be applied to measure students' progress (Bazaldua, et al. 2020). Classroom assessments provide real-time information to support teaching and learning in individual classrooms. Classroom assessments are classified as (1) Diagnostic classroom assessment, taken placed before any instruction to help teachers determine students initial knowledge and skills relative to the curriculum-based expectations; (2) Formative classroom assessment, is conducted as part of daily teaching practice and mostly to evaluate students understanding, to provide on-going feedback to teachers, and to monitor students' progress towards curriculum learning goal; (3) Summative classroom assessment, is conducted at the end of a curriculum unit or at the end of the school year to establish whether students achieve the learning goals specified in the curriculum.

Large-scale assessment will inform policymakers and practitioners about the progress on overall performance levels within the education system and what factors contribute to the student population's performance and certain subgroups of students. The comprehensive assessment could give a clear picture of students' progress, either loss or gain, and it will provide information for teachers, school administrators, and education policymakers to adjust instruction/learning methods and allocate resources accordingly, particularly to help students who suffer the most from the learning loss. 


\section{Tutoring Program}

Providing one-on-one or small group tutoring programs for students with a high magnitude of learning loss could be an option to reduce Covid-19 learning loss. The program could employ college students and fresh graduates as tutors. The tutoring program has been proven effective in improving student academic achievement, where students having academic tutors are likely to have their word-related test scores higher than their without-tutor peers (Ritter, G.W., et.al. 2009). Since the program aims to remedy the learning loss, the program could be in the out-ofschool time setting.

Research on this kind of program also showed a positive impact with a significant effect size on students' achievement (Heinrich, C.J., et al. 2014). The availability of a tutor to assist learning-loss-impacted students could help them progress their studies and catch up with their peers. The tutoring program could be considered as an additional learning time for students in need of extra help.

\section{Conclusion}

As a first step towards mitigating the potential adverse effects of the COVID-19 school closures on learning, countries worldwide have made great efforts to provide remote learning through various approaches. However, challenges remain in the implementation and effectiveness in supporting students' learning needs, making learning loss unavoidable. Globally, the school closure could cause students to lose 0.3 to 0.9 years of schooling, bringing effective years of schooling to be lower than ever before. The similar condition also possibly happens in Indonesia, which until July 2021 still have most of the school closed. The longer duration of remote learning increases the potential loss of learning, which later could bring challenges to the countries' economies. These conditions altogether put the most vulnerable students at a higher risk, including students in disadvantaged areas such as Manggarai Regency. It is recommended that teachers, educators, and policymakers take short and long-term countermeasures and preventable actions to diminish the potential impacts of learning loss today and in the long run. This paper also recommends conducting empirical research to measure the magnitude of learning loss in Manggarai to contextualise the preventive action.

\section{References}

[1] Arsendy, S., Gunawan, C. J., Rarasati, N., \& Suryadharma, D. (2020). Teaching and Learning During School Closure: Lessons from Indonesia. Singapore: ISEAS - Yusof Ishak Institute.

[2] Asian Development Bank (ADB). (2020). Learning and Earning Losses From Covid-19 School Closures in Developing Asia: Special Topic of the Asian Development Outlook 2021.

[3] Azevedo, J. P., et al. (2020). Simulating the Potential Impacts of COVID-19 School Closures on Schooling and Learning Outcomes: A Set of Global Estimates. World Bank Group.

[4] Badan Pusat Statistik Kabupaten Manggarai (BPS Manggarai). (2021). Kabupaten Manggarai dalam Angka 2021. Ruteng : Badan Pusat Statistik Kabupaten Manggarai

[5] Bazaldua, D. L., et.al. (2020). Guidance note on using learning assessment in the process of school reopening. World Bank Group.

[6] Bielinski, J., Brown, R., Wagner, K. (2020). COVID Slide: Research on Learning Loss \& Recommendations to Close The Gap. Minneapolis: Illuminate Education.

[7] Brown, N., et.al. (2020). Learning at Home During Covid-19: Effects on Vulnerable Young Australians. Report. 
[8] Peter Underwood Centre for Educational Attainment, University of Tasmania 2020.

[9] Clarke, M. (2012). What Matters Most for Students Assessment Systems: A Framework Paper. Systems Approach for Better Education Results (SABER), Student Assessment Working Paper, No.1. Washington, DC: World Bank.

[10] Di Pietro, G., Biagi, F., Costa, P., Karpiński Z., Mazza, J. (2020). The likely impact of COVID-19 on education: Reflections based on the existing literature and international datasets. Publications Office of the European Union, Luxembourg. Doi:10.2760/126686, JRC121071

[11] Dorn, E., et al. (2020). Covid-19 and Student Learning in the United States: The Hurt Could Last A Lifetime. McKinsey \& Company.

[12] Dorn, E., et al. (2020). Covid and Learning Loss - Disparities Grow and Students Need Help. Public \& Social Sector Practice, McKinsey \& Company.

[13] Engzell, P., Frey, A., \& Verhagen., M D. (2021). Learning Loss Due to School Closure During the COVID-19 Pandemic. PNAS (118) p 1-7

[14] Gupta, D. \& Khairina, N. N. (2020). COVID-19 and learning inequities in Indonesia: Four ways to bridge the gap. Retrieved from https://blogs.worldbank.org/eastasiapacific/covid-19-and-learninginequities-indonesia-four-ways-bridge-gap

[15] Heinrich, C. J., Burch, P., Good, A., Acosta, R., Cheng, H., Dillender, M., ... \& Stewart, M. (2014). Improving the implementation and effectiveness of out-of-school-time tutoring. Journal of Policy Analysis and Management, 33(2), 471-494.

[16] Indrawati, M., Pribadi, C., \& Siantoro, A (2020). The COVID-19 Pandemic Impact on Children's Education in Disadvantaged and Rural Areas Across Indonesia. International Journal of Education

[17] Jenkins, R. \& Benerji, R. (2021). How Can Formative Assessment Foster Learning As Schools Reopen?. Retrieved from https://blogs.unicef.org/evidence-for-action/how-can-assessment-fosterlearning-as-schools-reopen/

[18] Kementerian Pendidikan dan Kebudayaan. (2015). Neraca Pendidikan Daerah Provinsi Nusa Tenggara Timur. Jakarta : Kementerian Pendidikan dan Kebudayaan

[19] Kementerian Pendidikan dan Kebudayaan. (2019). Neraca Pendidikan Daerah 2019 Kabupaten Manggarai Nusa Tenggara Timur. Jakarta : Kementerian Pendidikan dan Kebudayaan

[20] Kuhfeld, M., et.al. (2020). Projecting the Potential Impact of COVID-19 School Closures on Academic Achievement. Educational Researcher, Vol. 49(8), pp. 549-565

[21] Maldonado, J. E. \& De Witte, K. (2020). The Effects of School Closure on Standardized Student Test Scores. FEB Research Report Department of Economics.

[22] McCombs, J., et.al. (2011). Time, Learning, Learning Decay, and Summer Learning Loss. In Making Summer Count: How Summer Programs Can Boost Children's Learning (pp. 17-26).

[23] Montenegro, C. E., \& Patrinos, H. A. (2014). Comparable Estimates of Returns to Schooling Around the World. Policy Research Working Paper No. 7020. World Bank.

[24] Patarapichayatham, C., Locke, V. N., \& Lewis, S. (2021). COVID-19 Learning Loss in Texas.

[25] Pier, L., Hough, H.J., Christian, M., Bookman, N., Wilkenfeld, B., \& Miller, R. (2021, January 25). COVID-19 and the educational equity crisis. Evidence on learning loss from the CORE data collaborative. PACE. https://www.edpolicyinca.org/newsroom/covid-19- and-educational-equitycrisis

[26] Pusat Penilaian Pendidikan. (2019). Distribusi Nilai UN Tahun Pelajaran 2018/2019. Jakarta : Puspendik.Retrievedfromhttps://hasilun.puspendik.kemdikbud.go.id/\#2019!smp!capaian_wilayah!2 $4 \& 99 \& 999$ !T\&T\&T\&T\&1\&!2!\&

[27] Rothstein, R. (2020). The Coronavirus Will Explode Achievement Gaps in Education.

[28] Ritter, G. W., Barnett, J. H., Denny, G. S., \& Albin, G. R. (2009). The effectiveness of volunteer tutoring programs for elementary and middle school students: A meta-analysis. Review of Educational Research, 79(1), 3-38.

[29] Yarrow, N., et.al. (2020). Estimates of COVID-19 Impacts on Learning and Earning in Indonesia: How to Turn the Tide. World Bank, Washington, DC. World Bank. https://openknowledge.worldbank.org/handle/10986/34378Budiardjo Miriam, (2008) Dasar-Dasar Ilmu Politik, Jakarta: Penerbit PT. Gramedia Pustaka Utama. 